\title{
PRIMJENA FUZZY VIŠEKRITERIJSKOG LINEARNOG PROGRAMIRANJA U RJEŠAVANJU PROBLEMA OPTIMIZACIJE PLANA PROIZVODNJE I TEHNOLOŠKIH VARIJANTI
}

\author{
APPLYING THE FUZZY MULTI-OBJECTIVE LINEAR \\ PROGRAMMING METHODOLOGY TO SOLVE A PROBLEM \\ OF PRODUCTION PLAN AND TECHNOLOGICAL VARIANTS \\ OPTIMIZATION
}

\begin{abstract}
SAŽETAK: U ovom se radu istražuje efikasnost primjene metodologije fuzzy višekriterijskog linearnog programiranja za rješavanje višekriterijskog problema optimizacije plana proizvodnje i tehnoloških varijanti u poduzeću koje se bavi proizvodnjom metalnih proizvoda. U radu se najprije prikazuje teorijski model višekriterijskog linearnog programiranja i metoda fuzzy višekriterijskog linearnog programiranja za njegovo rješavanje. Potom je prikazana metoda primijenjena na rješavanje konkretnog problema optimizacije plana proizvodnje i tehnoloških varijanti u poduzeću koje se bavi proizvodnjom metalnih proizvoda. Dobiveni rezultati ukazuju na mogućnost efikasne primjene ove metode u rješavanju konkretnog problema te na njene prednosti u odnosu na primjenu nekih drugih metoda (metoda STEM, metoda surogat vrijednosti razmjene).
\end{abstract}

KLJUČNE RIJEČI: optimizacija, proizvodni program, tehnološke varijante, višekriterijsko programiranje, fuzzy linearno programiranje.

ABSTRACT: This paper investigates the efficiency of applying the fuzzy multi-objective linear programming methodology to solve the multi-objective problem of the production plan and technological variants optimization in a company which deals with the production of metal products. The paper first presents the theoretical model of multi-objective linear programming and the fuzzy multi-objective linear programming method-

Paulina Dejanović, studentica diplomskog studija na Ekonomskom fakultetu Sveučilišta u Zagrebu, e-mail: pdejanovi@net.efzg.hr

Izv. prof. dr. sc. Tunjo Perić, izvanredni profesor na Katedri za matematiku Ekonomskog fakulteta Sveučilišta u Zagrebu, e-mail: tperic@efzg.hr 
ology for its solution. Then the presented method applies to solve the specific problem of optimization of production plan and technological variants in a company engaged in the production of metal products. The obtained results indicate the possibility of efficient application of this method in solving the specific problem and its advantages in relation to the application of some other methods (STEM method, Surrogate worth Trade-of Method).

KEY WORDS: optimization, production plan, technological variants, multi-objective programming, fuzzy linear programming.

\section{UVOD}

Optimizacija plana proizvodnje i tehnoloških varijanti predstavlja jedan od najznačajnijih problema s kojim se suočavaju proizvodna poduzeća. Po svojoj prirodi optimizacija plana proizvodnje i tehnoloških varijanti jest višekriterijski problem za čije se rješavanje mogu primijeniti metode višekriterijskog programiranja (Perić, 2008; Perić i Bratić, 2015.).

Za rješavanje problema višekriterijskog programiranja predložene su brojne metode (vidi: Perić, 2008; Matejaš i Perić, 2014.). Međutim, predložene metode višekriterijskog programiranja nisu jednako efikasne niti prema analitičkim kriterijima, a niti prema kriterijima donositelja odluke. Perić (2008.) navodi i klasificira brojne kriterije efikasnosti metoda višekriterijskog programiranja te naglašava problem odabira efikasne metode višekriterijskog programiranja pri rješavanju proizvodnih problema. Također, naglašava da ne postoji univerzalna metoda višekriterijskog programiranja koja bi bila jednako efikasna pri rješavanju svih problema višekriterijskog programiranja. Time istraživanje efikasnosti primjene različitih metoda višekriterijskog programiranja pri rješavanju optimizacijskih problema dobiva još veće značenje. Ovaj rad se bavi istraživanjem efikasnosti primjene metode fuzzy višekriterijskog linearnog programiranja pri rješavanju problema optimizacije plana proizvodnje i tehnoloških varijanti u poduzeću koje se bavi proizvodnjom metalnih proizvoda.

Metoda fuzzy višekriterijskog linearnog programiranja zasniva se na pretpostavci da donositelj odluke nije u stanju jasno odrediti aspiracijske razine funkcija cilja te da vrijednosti tehničkih, tehnoloških i tržišnih ograničenja nisu čvrsto definirane. Metoda pretpostavlja da je donositelj odluke u stanju odrediti donju i gornju granicu svojih aspiracija za svaku funkciju cilja, kao i intervale u kojima se nalaze vrijednosti ograničenja. Sama metoda koristi teoriju fuzzy skupova (Zadeh, 1965.) za određivanje funkcija pripadnosti vrijednosti funkcija cilja aspiracijskim intervalima tih funkcija, kao i za određivanje funkcija pripadnosti ograničenja definiranim intervalima u kojima se nalaze vrijednosti ograničenja. Nakon određivanja funkcija pripadnosti formira se model linearnog programiranja zasnovan na mini/max metodi (Lai i Hwang, 1996.).

Zimmermann (1978.) prvi uvodi prilaz fuzzy programiranja za rješavanje problema višekriterijskih problema. Daljnje istraživanje nastavili su Narasimhan (1980., 1981.), Hannan (1981.) i Ignizio (1982.), koji su uveli primjenu teorije fuzzy skupova pri rješavanju problema s višestrukim ciljevima. Nakon Zimmermannove metode fuzzy linearnog programiranja razvijene su brojne metode koje za rješavanje višekriterijskih problema koriste teoriju fuzzy skupova. Među tim metodama najvažnija je metoda fuzzy ciljnog programiranja s brojnim varijantama (Mohamed, 1996; Lai i Hwang, 1996; Hu, Teng i Li, 2007; Kumar, Kaur i Singh, 2011; Kumar i Kaur, 2013.). 
Metoda fuzzy ciljnog programiranja proširena je na upotrebu nelinearnih funkcija pripadnosti (Yang, Ignizio i Kim, 1991.) te na rješavanje višekriterijskih problema s prioritetima (Hu, Teng i Li, 2007.). Fuzzy ciljno programiranje primijenjeno je na rješavanje problema višekriterijskoga razlomljeno-linearnog programiranja (Ohta i Yamaguchy, 1996; Pal, Moitra i Maulik, 2003.) i višerazinskoga višekriterijskog linearnog programiranja (Baky, 2010.).

Brojne su primjene metoda fuzzy programiranja: u poljoprivredi i alokacijskim problemima (Sharma, Jana i Gaur, 2007.), odabiru portfelja financiranja (Parra, Terol i Uria, 2001.), rješavanju višekriterijskih problema transporta (Abd El-Wahed i Lee, 2006.).

Nakon uvoda u drugom dijelu rada se prikazuje značenje optimizacije plana proizvodnje i tehnoloških varijanti primjenom metoda matematičkog programiranja. Treći dio rada prikazuje metodu fuzzy višekriterijskog linearnog programiranja. U četvrtom dijelu rada prikazani su rezultati analize efikasnosti primjene metode fuzzy višekriterijskog linearnog programiranja pri rješavanju navedenog problema. Na kraju se navode zaključci i popis korištene literature.

\section{TEORIJSKO ZNAČENJE OPTIMIZACIJE PLANA PROIZVODNJE I TEHNOLOŠKIH VARIJANTI}

Proizvodni program zajednički je naziv za sve vrste i količine proizvoda koje poduzeće proizvodi. Podložan je promjenama odnosno poduzeća imaju slobodu mijenjati svoj proizvodni program u skladu s promjenama i zahtjevima tržišta, naravno ako im to dopuštaju tehnološke, tehničke i financijske mogućnosti, stoga bi poduzeća trebala planirati proizvodni program u dugom i kratkom roku.

Proizvodni program utječe na pozicioniranje poduzeća na tržištu, zbog toga bi svako poduzeće trebalo težiti ostvarivanju optimalnog proizvodnog programa. Takav program se definira kao onaj „koji poduzeću osigurava najvišu razinu rezultata poslovanja izraženu ekonomskim parametrima“" (Perić, 2008.).

Način proizvodnje odnosno postupak proizvodnje predmeta poslovanja nekog poduzeća naziva se tehnološkom varijantom. Pod predmetom poslovanja podrazumijeva se, naravno proizvod ili više njih čijom se proizvodnjom organizacija bavi. Nekada se proizvod može proizvesti na više različitih načina, a da bi poduzeće koje ga proizvodi ostvarivalo odgovarajuću dobit i poslovalo racionalno, treba izabrati onaj način ili tehnološku varijantu koja je najpovoljnija. Upravo ta „najpovoljnija tehnološka varijanta za proizvodnju određenog proizvoda jest ona varijanta po kojoj poduzeće ostvaruje najviši rezultat poslovanja izražen ekonomskim parametrima“ (Perić, 2008.). Ovako opisana tehnološka varijanta je optimalna te bi prema njoj poduzeće trebalo proizvoditi.

Optimizacija je definirana kao matematički postupak kojim se pri rješavanju određenoga problema određuje najbolji mogući izbor ekonomskih i tehničkih veličina prema unaprijed definiranim kriterijima. Optimizacija se promatra u okviru operacijskih istraživanja, koja se primjenjuju za rješavanje problema vođenja i koordinacije aktivnosti unutar organizacije. S obzirom da operacijska istraživanja probleme promatraju s različitih stajališta, razvijene su brojne metode za rješavanje različitih problema koji se razmatraju. Neki od 
problema mogu biti: određivanje optimalnog proizvodnog programa, tehnoloških varijanti, opterećenja strojeva, raspored radnika na radnim zadacima. Rješenje pojedinih navedenih problema može se dobiti korištenjem neke od metoda jednokriterijskog i višekriterijskog linearnog i nelinearnog programiranja, metoda simulacije, metoda asignacije i slično. Prema tome operacijska istraživanja primjenjiva su u područjima kao što su: transport, proizvodnja, ekonomija (financijsko planiranje), zdravstvo, vojska.

Ako se radi o većem broju ekonomskih problema prevedenih na matematički oblik, rješavanje će se sastojati u određivanju ekstrema, to jest minimuma ili maksimuma funkcije više varijabli uz dana ograničenja, pri čemu će rješenje biti ona alternativa koja je optimalna ili najbolja prema određenom kriteriju. Višekriterijsko programiranje pridonijelo je proširenju pojma optimalnosti jer uvodi koncept „Pareto optimalnosti“ $u$ metode za rješavanje modela višekriterijskog programiranja.

\section{MODEL VIŠEKRITERIJSKOG PROGRAMIRANJA I NJEGOVO RJEŠAVANJE METODOM FUZZY VIŠEKRITERIJSKOG LINEARNOG PROGRAMIRANJA}

Kao što sam naziv govori, višekriterijsko programiranje je proces u kojemu se traži rješenje problema matematičkog programiranja s više funkcija kriterija (cilja). To je „proces određivanja nedominiranih rješenja iz skupa mogućih rješenja i određivanje preferiranog rješenja iz skupa nedominiranih rješenja“ (Perić, 2008.). Koncept nedominiranosti karakterističan je u višekriterijskom programiranju, a naziva se još i Pareto optimalnost. Pareto optimalnost općenito označava stanje u kojemu se položaj jednog člana skupa ne može poboljšati, a da se pritom ne pogorša položaj nekog drugog člana skupa. Pareto optimalan skup je skup rješenja koja su međusobno nedominirana.

Kao što je već rečeno problem višekriterijskog programiranja je ukratko problem izbora vrijednosti za svaku od varijabli $x_{1}, x_{2}, \ldots, x_{n}$ vektora odlučivanja $\mathbf{x}^{T}=\left[x_{1}, x_{2}, \ldots, x_{n}\right]$, pri čemu se želi optimizirati $K(K \geq 2)$ funkcija cilja $f_{1}(\mathbf{x}), f_{2}(\mathbf{x}), \ldots, f_{K}(\mathbf{x})$ U problemu višekriterijskog programiranja pretpostavlja se da se želi maksimizirati (ili minimizirati) svaka od funkcija cilja istovremeno odnosno da se traže ekstremi funkcija cilja na zadanom skupu ograničenja. Ograničenja modela formiraju skup mogućih rješenja $\mathbf{S}$. U vezi s time, uzima se da je $\mathbf{x}$ (vektor varijabli odlučivanja) element skupa mogućih rješenja, tj. $\mathbf{x} \in \mathbf{S}, \mathbf{S} \subseteq \mathbf{R}^{n}$.

Prema navedenim uvjetima, model višekriterijskog programiranja može se prikazati na sljedeći način:

$$
\max \mathbf{f}=\left[f_{1}(\mathbf{x}), f_{2}(\mathbf{x}), \ldots, f_{K}(\mathbf{x})\right], K \geq 2
$$

pri čemu je

$$
\mathbf{x} \in \mathbf{S}
$$

Višekriterijsko programiranje se dijeli u dvije velike skupine: (1) višekriterijsko linearno i (2) višekriterijsko nelinearno programiranje. Višekriterijsko linearno programiranje, kojim se bavimo u ovom radu, poznaje brojne metode, kao što su: metoda globalnog kriterija, metoda funkcija korisnosti, linearno ciljno programiranje, metoda Surogat vrijednosti 
razmjene, metoda STEM i druge. Kako je rečeno u uvodnom dijelu, za potrebe ovoga rada opisat će se metoda fuzzy višekriterijskog linearnog programiranja. Kao uvod u metodu prvo će se objasniti pojam fuzzy logike.

Riječ fuzzy označava nešto neodređeno, nejasno, neizrazito, zamućeno ili zamrljano. Izraz koji je primjeren za potrebe ovoga rada jest nejasno. U okviru matematičkog programiranja fuzzy se odnosi na fuzzy (nejasan) problem odnosno na formuliranje istog. Kod uobičajenog linearnog programiranja parametri moraju biti definirani jasno i precizno te često postoji pretpostavka da se postavljeni ,,problem može riješiti samo ako je jasno formuliran“ (Barković, 1997.), međutim to nije pravilo. Problem linearnog programiranja moguće je postaviti i na način da zadrži fuzzy (nejasno) svojstvo. To potvrđuje i činjenica da su vrijednosti mnogih parametara linearnog programiranja procijenjene od strane eksperata (Kumar i Kaur, 2013.). Postavljanje problema odlučivanja u fuzzy obliku realističnije je i bolje prilagođeno stvarnim problemima. To dokazuje činjenica da znanje eksperata nije u potpunosti točno i precizno te da u stvarnosti često nije moguće parametre problema, čije se rješenje traži, definirati u savršenim uvjetima. Prema navedenim tvrdnjama moguće je zaključiti da bi bilo bolje problem linearnog programiranja definirati u fuzzy okolini.

Za fuzzy višekriterijsko linearno programiranje vezani su pojmovi funkcije pripadnosti i fuzzy broja.

Definicija 1: Funkcija pripadnosti

Ako se pretpostavi da za svaki podskup $A$ nekog temeljnog skupa $X$ postoji tzv. karakteristična funkcija: $f_{A}: X \rightarrow\{0,1\}$ koja za svaki element $x \in X$ kaže je li element skupa $A$ ili nije: $f_{A}(x)=1 \Leftrightarrow x \in A$ i $f_{A}(x)=0 \Leftrightarrow x \notin A$ (Bronstein et. al., 2004.). Za razliku od toga, može se izvesti relacija funkcije pripadnosti elementa $x$ skupu $A$ oblika:

$$
\mu_{A}: x \rightarrow[0,1] .
$$

Takva funkcija pripadnosti govori da se svakom elementu $x \in X$ pridružuje broj $\mu_{A}(x)$ iz intervala $[0,1]$, koji označava stupanj pripadnosti elementa $x$ skupu $A$ (Bronstein et. al., 2004.). Skup $A$, podskup je skupa $X$, koji je definiran na skupu realnih brojeva R. Skup $A$ naziva se fuzzy skup te vrijedi:

$$
A=\left\{\left(x, \mu_{A}(x)\right) ; x \in X\right\} .(\text { Kumar et. a.l, 2011.) }
$$

Definicija 2: Fuzzy broj

Fuzzy broj $A$, prikazan na način: $A=(a, b, c)$, bit će trokutasti fuzzy broj, ako je njegova funkcija pripadnosti sljedećeg oblika (Kumar et.al., 2011.):

$$
\mu_{A}(x)=\left\{\begin{array}{cc}
1 & x=b \\
\frac{x-a}{b-a} & a<x<b \\
\frac{x-c}{b-c} & b<x<c \\
0 & x \leq a \wedge x \geq c .
\end{array}\right.
$$


Za trokutasti fuzzy broj $(a, b, c)$ se kaže da je nenegativan fuzzy broj ako je $a \geq 0$. Također, važno je navesti da će dva fuzzy broja $A=(a, b, c)$ i $B=(e, f, g)$ biti jednaka samo ako vrijedi da je $a=e, b=f$ i $c=g$.

Klasičan model fuzzy višekriterijskog linearnog programiranja može se prikazati na sljedeći način:

Funkcije cilja:

$$
\max \mathbf{x}^{T} \mathbf{c}_{k} \cong f_{k}, k=1, \ldots, K
$$

uz ograničenja:

$$
\begin{aligned}
& \mathbf{A x} \cong \mathbf{b} \\
& \mathbf{x} \geq \mathbf{0}
\end{aligned}
$$

gdje su:

- $\mathbf{c}_{k}=$ vektor koeficijenata $k$-te funkcije cilja

- A = matrica koeficijenata sustava ograničenja

- $\mathbf{x}=$ vektor varijabli odlučivanja

- $\mathbf{b}=$ vektor vrijednosti ograničenja,

- a $\cong$ označava približno jednako.

Nakon definiranja osnovnog modela, potrebno je izvesti funkcije pripadnosti ograničenja i funkcije pripadnosti funkcija cilja. Pripadajuća funkcija pripadnosti ograničenja modela glasi:

$$
\mu_{i}\left(\mathbf{a}_{i}^{T} \mathbf{x}\right)=\left\{\begin{array}{ccc}
0 & z a & \mathbf{a}_{i}^{T} \mathbf{x} \leq b_{i}-d_{b_{i}} \wedge \mathbf{a}_{i}^{T} \mathbf{x} \geq b_{i}+d_{b_{i}} \\
1-\frac{\mathbf{a}_{i}^{T} \mathbf{x}-b_{i}}{d_{b_{i}}} & z a & b_{i}<\mathbf{a}_{i}^{T} \mathbf{x}<b_{i}+d_{b_{i}} \\
1-\frac{b_{i}-\mathbf{a}_{i}^{T} \mathbf{x}}{d_{b_{i}}} & z a & b_{i}-d_{b_{i}}<\mathbf{a}_{i}^{T} \mathbf{x}<b_{i}
\end{array}\right.
$$

gdje parametar $d_{b_{i}}(i=1,2, \ldots, m)$ označava vrijednost za koju je maksimalno moguće podbaciti odnosno prekoračiti ograničenje $b_{i}$.

Funkcija pripadnosti $k$-te funkcije cilja je:

$$
\mu_{f_{k}}\left(\mathbf{x}^{T} \mathbf{c}_{k}\right)=\left\{\begin{array}{ccc}
0 & z a & \mathbf{x}^{T} \mathbf{c}_{k} \leq z_{k_{D}} \\
\frac{\mathbf{x}^{T} \mathbf{c}_{k}-f_{k_{D}}}{f_{k_{G}}-f_{k_{D}}} & z a & f_{k_{D}}<\mathbf{x}^{T} \mathbf{c}_{k}<f_{k_{G}} . \\
1 & z a & \mathbf{x}^{T} \mathbf{c}_{k} \geq f_{k_{G}}
\end{array}\right.
$$

S obzirom da je fuzzy višekriterijsko linearno programiranje metoda višekriterijskog programiranja, u kojemu se pojavljuje više funkcija cilja, problem koji nastaje sastoji se u „međusobnom uspoređivanju različitih ciljeva“ (Barković, 1997.). Što znači da se na jednoj 
strani pokušava maksimizirati vrijednost prvotne jasno formulirane funkcije cilja $z$, dok se na drugoj strani želi postići što je moguće veće zadovoljstvo donositelja odluke u pogledu restrikcija (Sharma et. al., 2007.). Radi toga se formulira i funkcija pripadnosti različitih vrijednosti funkcije cilja $z_{k}$. Navedena funkcija pripadnosti prikazuje koliko neka funkcija postiže vrijednosti između 0 i $1, \mathrm{tj} . \mu_{z_{k}}\left(x^{T} c_{k}\right) \in[0,1]$ (Sharma et. al., 2007.). Prema tome, potrebno je odrediti donju i gornju aspiracijsku razinu funkcija cilja. Donja aspiracijska razina funkcije cilja $z_{k_{L}}$ je ona ispod koje se ne smije ići, dok je gornja granica tolerancije $z_{k_{U}}$ - ona koju se ne smije prekoračiti ,i kojom bi donositelj odluke trebao biti u potpunosti zadovoljan“ (Barković, 1997.). Opisane vrijednosti određuje donositelj odluke na temelju tablice isplata i njegovih preferencija. Tablica isplata je tablica koja prikazuje vrijednosti svih funkcija cilja za ostvarene optimalne vrijednosti funkcija cilja.

Navedeni uvjeti, malo ili veliko prekoračenje granica zadanih ograničenja te minimalne i maksimalne vrijednosti funkcija cilja odnosno donje i gornje aspiracijske razine „predstavljaju suprotne ciljeve koji se moraju agregirati u jednu novu funkciju“ (Barković, 1997.). Kao što je već rečeno, u stvarnosti nije moguće precizno odrediti vrijednosti ciljeva i ograničenja, stoga je prihvatljivije koristiti jezično nejasnu izjavu „približno ili otprilike“. U skladu s time, može se formulirati sljedeći model višekriterijskog programiranja:

naći takvo $\mathbf{x}$

uz ograničenja:

$$
\begin{gathered}
\mathbf{x}^{T} \mathbf{c}_{k} \cong \tilde{z}_{k}, k=1, \ldots, K \\
(\mathbf{A x})_{i} \cong \tilde{b}_{i}, i=1, \ldots, m, \\
\mathbf{x} \geq 0
\end{gathered}
$$

Gdje $\tilde{z}_{k}, \forall k$ i $\tilde{b}_{i}, \forall i$, izražavaju ciljeve kao na primjer: ,profit bi trebao biti oko $z_{k}$ odnosno vrijednost ograničenja bi trebala biti oko $b_{i}$ (Lai i Hwang, 1996.).

Uzimajući u obzir funkcije pripadnosti, rješenje modela (8) svodi se na rješavanje sljedećeg modela linearnog programiranja:

uz ograničenja:

$$
\begin{aligned}
& \mu_{z_{k}}\left(\mathbf{x}^{T} \mathbf{c}_{k}\right) \geq \lambda, k=1, \ldots, K \\
& \mu_{i}\left(\mathbf{a}_{i}^{T} \mathbf{x}\right) \geq \lambda, i=1, \ldots, m \\
& \mathbf{x} \geq 0
\end{aligned}
$$

gdje predstavlja novu varijablu koja se uvodi u model i koja se želi maksimizirati, a naziva se minimalni operator odnosno funkcija cilja maksimizira minimalno zadovoljstvo. 


\section{ANALIZA EFIKASNOSTI PRIMJENE METODE FUZZY VIŠEKRITERIJSKOG LINEARNOG PROGRAMIRANJA PRI OPTIMIZACIJI PLANA PROIZVODNJE I TEHNOLOŠKIH VARIJANTI}

Četvrto poglavlje ovoga rada pokazat će na primjeru poduzeća iz metalne industrije kakva je efikasnost primjene fuzzy višekriterijskog linearnog programiranja u rješavanju problema optimizacije plana proizvodnje i tehnoloških varijanti. Podaci za postavljanje modela preuzeti su iz (Perić, 2008.).

\section{Postavljanje problema}

Poduzeće za razdoblje siječanj - prosinac tekuće godine, pored pojedinačne proizvodnje po narudžbi, predviđa proizvodnju 11 različitih proizvoda koje ćemo označiti brojevima 1 do 11 . Neto prodajna cijena, bruto-dobit i neto-dobit po proizvodu prikazani su u sljedećoj tablici:

Tablica 1. Neto prodajna cijena, bruto-dobit i neto-dobit po proizvodu

\begin{tabular}{|c|c|c|c|}
\hline Proizvod $(i)$ & $\begin{array}{c}\text { Neto prodajna cijena } \\
\left(c_{i, g 3}\right)\end{array}$ & Bruto-dobit & $\begin{array}{c}\text { Neto-dobit } \\
\left(c_{i, g 1}\right)\end{array}$ \\
\hline 1 & 12,80 & 3,07 & 0,77 \\
\hline 2 & 78,00 & 18,72 & 4,68 \\
\hline 3 & 14,50 & 3,84 & 0,87 \\
\hline 4 & 10,80 & 2,59 & 0,65 \\
\hline 5 & 9,81 & 2,35 & 5,89 \\
\hline 6 & 13,60 & 3,26 & 0,82 \\
\hline 7 & 15,80 & 3,79 & 0,95 \\
\hline 8 & 20,30 & 4,87 & 1,22 \\
\hline 9 & 19,80 & 4,75 & 1,19 \\
\hline 10 & 13,45 & 3,23 & 0,81 \\
\hline 11 & 218,50 & 52,44 & 13,11 \\
\hline
\end{tabular}

Izvor: Perić (2008.).

Za proizvodnju različitih proizvoda predviđen je utrošak različite količine direktno proizvodnog rada, koji je različit po pojedinim varijantama. Utrošak direktno proizvodnog rada po proizvodima i varijantama te koeficijenti ekvivalencije dobiveni dijeljenjem potrebnog radnog vremena za proizvodnju svakog proizvoda po različitim varijantama potrebnim radnim vremenom za proizvodnju proizvoda 3 (prema autorovom slobodnom odabiru) po različitim varijantama prikazani su u sljedećoj tablici:

Pretpostavlja se da bruto-dobit i neto-dobit po proizvodu ne ovise o tehnološkoj varijanti po kojoj je proizvod izrađen. 
Tablica 2. Utrošak direktno-proizvodnog rada i koeficijenti ekvivalencije

\begin{tabular}{|c|c|c|c|c|c|c|c|c|}
\hline \multirow[b]{2}{*}{$\begin{array}{l}\overrightarrow{0} \\
\stackrel{2}{0} \\
\stackrel{0}{0}\end{array}$} & \multicolumn{8}{|c|}{ Utrošak direktno proizvodnog rada u minutama i koeficijenti ekvivalencije } \\
\hline & $\begin{array}{l}\widehat{i} \\
\dot{\vec{\sigma}} \\
\dot{\sigma}\end{array}$ & 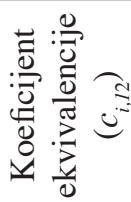 & 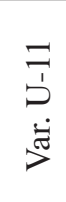 & 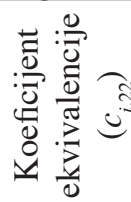 & $\begin{array}{l}u^{\prime} \\
\dot{z} \\
\dot{z} \\
z^{\prime}\end{array}$ & 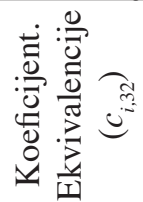 & 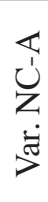 & 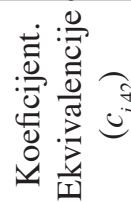 \\
\hline 1 & 18 & 1,28 & - & 0,00 & 9 & 1,80 & 7 & 1,40 \\
\hline 2 & 132 & 9,43 & - & 0,00 & 66 & 13,20 & - & 0,00 \\
\hline 3 & 14 & 1,00 & 10 & 1,00 & 5 & 1,00 & 5 & 1,00 \\
\hline 4 & 15 & 1,07 & 9 & 0,90 & - & 0,00 & - & 0,00 \\
\hline 5 & 9 & 0,64 & 8 & 0,80 & 5 & 1,00 & 3 & 0,60 \\
\hline 6 & 13 & 0,93 & 12 & 1,20 & 6 & 1,20 & 5 & 1,00 \\
\hline 7 & 22 & 1,57 & 20 & 2,00 & - & 0,00 & - & 0,00 \\
\hline 8 & 30 & 2,14 & 25 & 2,50 & - & 0,00 & - & 0,00 \\
\hline 9 & 18 & 1,28 & 14 & 1,40 & 11 & 2,20 & - & 0,00 \\
\hline 10 & 14 & 1,00 & 11 & 1,10 & 7 & 1,40 & 5 & 1,00 \\
\hline 11 & 250 & 17,80 & 200 & 20 & 145 & 29 & - & 0,00 \\
\hline
\end{tabular}

Izvor: Perić (2008.).

Proizvodni pogon za struganje sastoji se od 7 strojeva za struganje U-7 (univerzalni poluautomatski stroj), jednog stroja U-11 (univerzalni poluautomatski stroj), 2 stroja NC-P (namjenski poluautomatski stroj) i jednog stroja NC-A (namjenski automatski stroj). Potrebna vremena izrade pojedinih proizvoda na navedenim strojevima za struganje prikazana su u tablici 3.

Tablica 3. Vrijeme rada strojeva za struganje

\begin{tabular}{|c|c|c|c|c|}
\hline \multirow{2}{*}{ Proizvod (i) } & \multicolumn{4}{|c|}{ Vrijeme rada strojeva za struganje u minutama ${ }^{2}$} \\
\hline & Var. U-7 $\left(a_{i, 1}\right)$ & Var. U-11 $\left(a_{\text {.2 }}\right)$ & Var. NC-P $\left(a_{i 2}\right)$ & Var. NC-A $\left(a_{i 4}\right)$ \\
\hline 1 & 10 & - & 6 & 5 \\
\hline 2 & 80 & - & 40 & - \\
\hline 3 & 8 & 8 & 4 & 4 \\
\hline 4 & 5 & 5 & - & - \\
\hline 5 & 4 & 5 & 3 & 2 \\
\hline 6 & 6,5 & 6,5 & 3 & 3 \\
\hline 7 & 6 & 5,5 & - & - \\
\hline 8 & 25 & 21 & - & - \\
\hline 9 & 6,5 & 5,8 & 5 & - \\
\hline 10 & 12 & 10 & 7 & 5 \\
\hline 11 & 47 & 39 & 30 & - \\
\hline Raspoloživi kapacitet & 405000 & 101000 & 130460 & 99490 \\
\hline
\end{tabular}

Izvor: Perić (2008.).

Vrijeme rada na izradi proizvoda pored operacije struganja uključuje i neke druge operacije (sječenje, glodanje, brušenje, termička obrada). Neke od ovih operacija obavljaju se na stroju za struganje, što ovisi o vrsti proizvoda i vrsti stroja za struganje. Operacija struganja na pojedinim vrstama strojeva obavlja se s različitim finoćama, što ima za posljedicu neke dodatne operacije u cilju kvalitetne obrade proizvoda pa prema tome, dodatno vrijeme za izradu proizvoda ovisi o vrsti stroja za struganje. Budući da je kod ovih proizvoda struganje najznačajnija operacija, odabir tehnoloških varijanti izvršit će se imajući u vidu ovu operaciju. 
Potrošnja osnovnog materijala u kilogramima za izradu pojedinih proizvoda na određenim strojevima za struganje prikazana je u tablici 4.

Tablica 4. Potrošnja osnovnog materijala u kilogramima

\begin{tabular}{|c|c|c|c|c|}
\hline \multirow{2}{*}{ Proizvod } & \multicolumn{4}{|c|}{ Potrošnja osnovnog materijala u kilogramima } \\
\cline { 2 - 5 } & Var. U-7 $\left(b_{i 1}\right)$ & Var. U-11 $\left(b_{i 2}\right)$ & Var. NC-P $\left(b_{i 3}\right)$ & Var. NC-A $\left(b_{i 4}\right)$ \\
\hline 1 & 0,41 & - & 0,40 & 0,40 \\
\hline 2 & 1,75 & - & 1,70 & - \\
\hline 3 & 0,35 & 0,35 & 0,34 & 0,34 \\
\hline 4 & 0,40 & 0,40 & - & - \\
\hline 5 & 0,49 & 0,47 & 0,45 & 0,44 \\
\hline 6 & 0,36 & 0,35 & 0,35 & 0,33 \\
\hline 7 & 0,71 & 0,69 & - & - \\
\hline 8 & 0,66 & 0,65 & - & - \\
\hline 9 & 0,42 & 0,41 & 0,41 & 0,30 \\
\hline 10 & 0,33 & 0,31 & 0,30 & - \\
\hline 11 & 3,15 & 3,10 & 3,05 & \\
\hline
\end{tabular}

Izvor: Perić (2008.).

Ograničena je mogućnost nabave osnovnog materijala u navedenom vremenskom razdoblju na $46000 \mathrm{~kg}$.

Budući da se radi o specifičnim proizvodima, koji su namijenjeni uskom krugu kupaca, poduzeće ima ograničenja u pogledu mogućnosti prodaje, tako da se predviđa za naredni planski period: najviše se može prodati: 7500 komada proizvoda 1; 4500 komada proizvoda 2; 14500 komada proizvoda 3; 8000 komada proizvoda 4; 25500 komada proizvoda 5; 15500 komada proizvoda 6; 9500 komada proizvoda 7; 4500 komada proizvoda 8; 8500 komada proizvoda 9; 8500 komada proizvoda 10 i 4500 komada proizvoda 11.

Na osnovi prethodno navedenih podataka može se formirati model višekriterijskog linearnog programiranja. Poduzeće je odlučilo maksimizirati funkciju bruto-dobiti i funkciju obujma proizvodnje, a budući da poduzeće izvozi proizvode 1, 3, 4, 5 i 10, funkcija prihoda ostvarenog izvozom treća je funkcija cilja koja će se maksimizirati.

\section{Postavljanje modela}

U nastavku će se formirati funkcije cilja i pripadajuća ograničenja modela. Neka je $x_{i, g}$ količina $i$-tog proizvoda izrađenog po $g$-toj tehnološkoj varijanti $i \in\{1, \ldots, 11\}, g \in\{1$, $\ldots, 4\}$

\section{Funkcije cilja:}

Bruto - dobit:

$$
\max f_{1}=\sum_{i=1}^{11} \sum_{g=1}^{4} c_{i, g 1} x_{i, g},
$$

gdje je $c_{i, g 1}$ neto profit iz tablice 1 . 
Obujam proizvodnje:

$$
\max f_{2}=\sum_{i=1}^{1} c_{i, 12} x_{i, 1}+\sum_{i=1}^{1} c_{i, 22} x_{i, 2}+\sum_{i=1}^{1} c_{i, 32} x_{i, 3}+\sum_{i=1}^{1} c_{i, 42} x_{i, 4}
$$

gdje su $c_{i, 12}, c_{i, 22}, c_{i, 32}, c_{i, 42}$ koeficijenti ekvivalencije iz tablice 2 .

Prihod ostvaren izvozom:

$$
\max f_{3}=\sum_{i \in I} \sum_{g=1}^{4} c_{i, g 3} x_{i, g},
$$

gdje su $c_{i, 83}$ neto prodajne cijene iz tablice 1 , dok je $I=\{1,3,4,5,10\}$

\section{Ograničenja:}

Strojevi U-7:
(1) $\sum_{i=1}^{11} a_{i, 1} x_{i, 1} \leq 405000$,
(2) $\sum_{i=1}^{11} a_{i, 2} x_{i, 2} \leq 101000$,
(3) $\sum_{i=1}^{11} a_{i, 3} x_{i, 3} \leq 130460$,
$\sum_{i=1}^{11} a_{i, 4} x_{i, 4} \leq 99490$,

Ograničenje sirovine:

(5) $\sum_{i=1}^{11} b_{i 1} x_{i 1}+\sum_{i=1}^{11} b_{i 2} x_{i 2}+\sum_{i=1}^{11} b_{i 3} x_{31}+\sum_{i=1}^{11} b_{i 4} x_{i 4} \leq 46000$,

Tržišni kapacitet
(6) $x_{1,1}+x_{1,3}+x_{1,4} \leq 7500$
(7) $x_{2,1}+x_{2,3} \leq 4500$
(8) $x_{3,1}+x_{3,2}+x_{3,3}+x_{3,4} \leq 14500$
(9) $x_{4,1}+x_{4,2} \leq 8000$
(10) $x_{5,1}+x_{5,2}+x_{5,3}+x_{5,4} \leq 25500$
(11) $x_{6,1}+x_{6,2}+x_{6,3}+x_{6,4} \leq 15500$
(12) $x_{7,1}+x_{7,2} \leq 9500$
(13) $x_{8,1}+x_{8,2} \leq 4500$
(14) $x_{9,1}+x_{9,2}+x_{9,3} \leq 8500$
(15) $x_{10,1}+x_{10,2}+x_{10,3}+x_{10,4} \leq 8500$
(16) $x_{11,1}+x_{11,2}+x_{11,3} \leq 4500$

Ograničenje nenegativnosti varijabli

(17) $x_{i, g} \geq 0, i \in\{1, \ldots, 11\}, g \in\{1, \ldots, 4\}$

Model (3.10) je model višekriterijskog linearnog programiranja sastavljen od tri funkcije cilja i 16 ograničenja. Model je najprije riješen primjenom metode linearnog programiranja zasebno maksimizirajući svaku od tri funkcije cilja na danom skupu ograničenja. Dobivena rješenja prikazana su u tablici 5 . 
Tablica 5: Tablica isplata - marginalna rješenja

\begin{tabular}{|c|c|c|c|c|}
\hline \multirow{2}{*}{ Rješenje } & \multirow{2}{*}{ Vrijednosti varijabli } & \multicolumn{3}{|c|}{ Vrijednosti funkcija cilja } \\
\hline & & $f_{1}$ & $f_{2}$ & $f_{3}$ \\
\hline $\max f_{1}$ & $\begin{array}{ll}x_{2,1}=2199, & x_{2,3}=2074, \\
x_{3,3}=11877, & x_{3,4}=2611, \\
x_{4,1}=8000, & x_{6,4}=15500, \\
x_{7,1}=7347, & x_{9,1}=8500, \\
x_{10,4}=8500, & x_{11,1}=1910, \\
x_{11,2}=2590 & \end{array}$ & 533344 & 203499,76 & 410960,50 \\
\hline $\max f_{2}$ & $\begin{array}{l}x_{1,4}=7500, \\
x_{3,4}=3872, \\
x_{5,1}=4369, \\
x_{7,2}=9500, \\
x_{9,2}=7388, \\
x_{11,3}=4369\end{array}$ & 510011,59 & 241245 & 281403,89 \\
\hline $\max f_{3}$ & $\begin{array}{l}x_{1,1}=7500, \quad x_{4,1}=8000 \\
x_{3,1}=14500, x_{5,1}=25500 \\
x_{10,1}=8500\end{array}$ & 181585 & 156756 & 757130 \\
\hline
\end{tabular}

Izvor: autori.

Iz tablice 5. je vidljivo da imamo tri rješenja koja daju različite vrijednosti funkcijama cilja pa je donositelju odluke teško donijeti odluku o odabiru za njega najboljeg rješenja.

Rješenja prikazana u tablici 5. bit će potrebna u nastavku rada, jer su to referentne vrijednosti na temelju kojih će donositelj odluke odrediti donje i gornje razine aspiracijskih vrijednosti funkcija cilja. Autori ovoga rada preuzeli su ulogu donositelja odluke te su za funkcije cilja odredili donju $\left(f_{k \mathrm{D}}\right)$ i gornju razinu $\left(f_{k \mathrm{G}}\right)$ svojih aspiracija $(k \in\{1,2,3\})$, dok su za ograničenja pretpostavili da su fiksno zadana:

$$
f_{1 \mathrm{D}}=181585, f_{1 \mathrm{G}}=533344, f_{2 \mathrm{D}}=156756, f_{2 \mathrm{G}}=241245, f_{3 \mathrm{D}}=281403,89, f_{3 \mathrm{G}}=757139 .
$$

Na temelju zadanih donjih i gornjih aspiracijskih razina formiraju se funkcije pripadnosti funkcija cilja.

Funkcija pripadnosti funkcija cilja izgledaju ovako:

$$
\mu_{1}\left(f_{1}(x)\right)=\left\{\begin{array}{ccc}
0 & \text { ako je } & f_{1}(x) \leq 181585 \\
\frac{f_{1}(x)-181585}{533344-181585} & \text { ako je } & 181585<f_{1}(x)<533344 \\
1 & \text { ako je } & f_{1}(x) \geq 533344
\end{array}\right.
$$




$$
\begin{gathered}
\mu_{2}\left(f_{2}(x)\right)=\left\{\begin{array}{ccc}
0 & \text { ako je } & f_{2}(x) \leq 156756 \\
\frac{f_{2}(x)-156756}{241245-156756} & \text { ako je } & 156756<f_{1}(x)<241245 \\
1 & \text { ako je } & f_{2}(x) \geq 241245
\end{array}\right. \\
\mu_{3}\left(f_{3}(x)\right)=\left\{\begin{array}{cccc}
0 & \text { ako je } & f_{3}(x) \leq 281403,89 \\
\frac{f_{3}(x)-281403,89}{757130-281403,89} & \text { ako je } & 281403,89<f_{1}(x)<757130 \\
1 & \text { ako je } & f_{1}(x) \geq 757130
\end{array}\right.
\end{gathered}
$$

Zatim se funkcija pripadnosti preoblikuje u ograničenja modela fuzzy višekriterijskog linearnog programiranja:

$$
\begin{aligned}
& \frac{f_{1}(x)-181585}{533344-181585} \geq \lambda \Leftrightarrow f_{1}(x)-351759 \lambda \geq 181585 \\
& \frac{f_{2}(x)-156756}{241245-156756} \geq \lambda \Leftrightarrow f_{2}(x)-84489 \lambda \geq 156756 \\
& \frac{f_{3}(x)-281403,89}{757130-281403,89} \geq \lambda \Leftrightarrow f_{3}(x)-475726,11 \lambda \geq 281403,89
\end{aligned}
$$

Nakon što su izvedene, potrebne funkcije pripadnosti uvrštavaju se u prethodno prikazan model (9). Prema tome model fuzzy višekriterijskog linearnog programiranja sada glasi:

uz ograničenja

$$
\begin{aligned}
& f_{1}(x)-351759 \lambda \geq 181585 ; f_{2}(x)-84489 \lambda \geq 156756 ; f_{3}(x)-475726,11 \lambda \geq 281403,89 \text {; } \\
& \sum_{i=1}^{11} a_{i 1} x_{i 1} \leq 405000 ; \sum_{i=1}^{11} a_{i 2} x_{i 2} \leq 101000 ; \sum_{i=1}^{11} a_{i 3} x_{i 3} \leq 130460 ; \sum_{i=1}^{11} a_{i 4} x_{i 4} \leq 99490 ; \\
& \sum_{i=1}^{11} b_{i 1} x_{i 1}+\sum_{i=1}^{11} b_{i 2} x_{i 2}+\sum_{i=1}^{11} b_{i 3} x_{31}+\sum_{i=1}^{11} b_{i 4} x_{i 4} \leq 46000 ; x_{1,1}+x_{1,3}+x_{1,4} \leq 7500, x_{1,1}+x_{1,3}+x_{1,4} \leq 7500 \\
& \text {; } \quad x_{2,1}+x_{2,3} \leq 4500 ; \quad x_{3,1}+x_{3,2}+x_{3,3}+x_{3,4} \leq 14500 ; \quad x_{4,1}+x_{4,2} \leq 8000 ; \\
& x_{5,1}+x_{5,2}+x_{5,3}+x_{5,4} \leq 25500 ; \quad x_{6,1}+x_{6,2}+x_{6,3}+x_{6,4} \leq 15500 ; \quad x_{7,1}+x_{7,2} \leq 9500 ; \\
& x_{8,1}+x_{8,2} \leq 4500 ; \quad x_{9,1}+x_{9,2}+x_{9,3} \leq 8500 ; \quad x_{10,1}+x_{10,2}+x_{10,3}+x_{10,4} \leq 8500 ; \\
& x_{11,1}+x_{11,2}+x_{11,3} \leq 4500 ; x_{i, g} \geq 0, i \in\{1, \ldots, 11\}, g \in\{1, \ldots, 4\} \text {. }
\end{aligned}
$$

Rješenje ovoga fuzzy linearnog modela dobiveno je pomoću Microsoft Excel Solvera koji koristi simpleks metodu za rješavanje problema linearnog programiranja (tablica 6.). 
Tablica 6: Nedominirano rješenje modela fuzzy višekriterijskog linearnog programiranja

\begin{tabular}{|c|c|c|c|c|}
\hline \multirow{2}{*}{ Rješenje } & \multirow{2}{*}{ Vrijednosti varijabli } & \multicolumn{3}{|c|}{ Vrijednosti funkcija cilja } \\
\hline & & $f_{1}$ & $f_{2}$ & $f_{3}$ \\
\hline Model (17) & 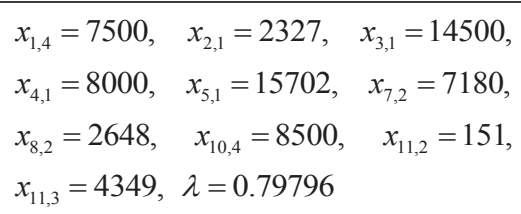 & $\begin{array}{c}478217 \\
(90 \% \text { od } \\
\left.z_{1}^{*}\right)\end{array}$ & $\begin{array}{c}224175 \\
(93 \% \text { od } \\
\left.z_{2}^{*}\right)\end{array}$ & $\begin{array}{c}661014 \\
(87 \% \text { od } \\
\left.z_{3}^{*}\right)\end{array}$ \\
\hline
\end{tabular}

Izvor: autor.

Tablica 7: Iskorištenost pojedinih ograničenja

\begin{tabular}{|l|c|}
\hline \multicolumn{1}{|c|}{ Ograničenje } & Iskorištenost ograničenja \\
\hline Raspoloživi kapacitet strojeva U-7 & $100 \%$ \\
\hline Raspoloživi kapacitet strojeva U-11 & $100 \%$ \\
\hline Raspoloživi kapacitet strojeva NC-P & $100 \%$ \\
\hline Raspoloživi kapacitet strojeva NC-A & $80,41 \%$ \\
\hline Ograničenje raspoloživih sirovina & $100 \%$ \\
\hline Prodaja proizvoda 1 & $100 \%$ \\
\hline Prodaja proizvoda 3 & $100 \%$ \\
\hline Prodaja proizvoda 4 & $100 \%$ \\
\hline Prodaja proizvoda 5 & $61,58 \%$ \\
\hline Prodaja proizvoda 6 & $0,00 \%$ \\
\hline Prodaja proizvoda 7 & $75,58 \%$ \\
\hline Prodaja proizvoda 9 & $0,00 \%$ \\
\hline Prodaja proizvoda 10 & $100 \%$ \\
\hline Prodaja proizvoda 2 & $51,72 \%$ \\
\hline Prodaja proizvoda 8 & $58,84 \%$ \\
\hline Prodaja proizvoda 11 & $100 \%$ \\
\hline
\end{tabular}

Izvor: autori.

Kako bi donositelj odluke procijenio je li dobiveno rješenje zadovoljavajuće, usporedit će ga s marginalnim rješenjima iz tablice 5. (vidljivo u tablici 6.) te ce izračunati vrijednosti funkcija pripadnosti uvrštavanjem dobivenih vrijednosti funkcija cilja u relaciju (11), (12) i (13):

$$
\mu_{1}\left(f_{1}(x)\right)=0,8433, \quad \mu_{2}\left(f_{2}(x)\right)=0,798, \quad \mu_{3}\left(f_{3}(x)\right)=0,798 .
$$

Primjećujemo da se odstupanja dobivenih vrijednosti funkcija cilja od njihovih marginalnih vrijednosti nalaze između 87 i 93 posto, dok se odgovarajuće funkcije pripadnosti kreću od 0,798 do 0,8433. To nam kazuje da smo dobili rješenje koje svim funkcijama cilja daje približno jednako značenje, što ovoj metodi daje značajnu prednost u odnosu na neke druge metode višekriterijskog programiranja. Rješenje dobiveno primjenom ove metode usporedili smo s rješenjima dobivenim metodom STEM i metodom SWT (Perić, 2008.): 
Tablica 8: Dobivena rješenja metodama STEM i SWT

\begin{tabular}{|l|c|c|c|}
\hline Metoda & $f_{1}$ & $f_{2}$ & $f_{3}$ \\
\hline STEM & $519706,93\left(97 \%\right.$ od $\left.f_{1}^{*}\right)$ & $224968\left(93 \%\right.$ od $\left.f_{2}^{*}\right)$ & $650000\left(86 \%\right.$ od $\left.f_{3}^{*}\right)$ \\
\hline SWT & $519705.2\left(97 \%\right.$ od $\left.f_{1}^{*}\right)$ & $225245\left(93 \%\right.$ od $\left.f_{2}^{*}\right)$ & $650000\left(86 \%\right.$ od $\left.f_{3}^{*}\right)$ \\
\hline
\end{tabular}

Izvor: Perić (2008.).

Iz tablice 8. vidimo da su metode STEM i SWT dale približno jednaka rješenja koja se razlikuju od rješenja dobivenog primjenom metode fuzzy višekriterijskog linearnog programiranja. Metoda fuzzy višekriterijskog linearnog programiranja daje nešto veću vrijednost funkciji $f_{3}$, a manju vrijednost funkciji $f_{1}$ Prema tome, metoda fuzzy višekriterijskog linearnog programiranja dala je rješenje koje funkcijama cilja daje vrijednosti s postotkom ostvarenja marginalnih vrijednosti funkcija cilja između 87 i $93 \%$, za razliku od metoda STEM i SWT koje su dale rješenja s vrijednostima funkcija cilja koje imaju postotak ostvarenja njihovih marginalnih vrijednosti između 86 i $97 \%$.

Metoda fuzzy višekriterijskog linearnog programiranja ima prednost u odnosu na metode STEM i SWT jer od donositelja odluke traži jedino informaciju o donjim i gornjim aspiracijskim razinama funkcija cilja, koje nije teško osigurati. Te se informacije čak mogu preuzeti iz tablice isplata. Metode STEM i SWT su interaktivne metode koje od donositelja odluke traže aktivno sudjelovanje u procesu rješavanja problema osiguravajući brojne informacije vezane uz relativnu važnost funkcija cilja, kao i mogućnost prepoznavanja preferiranog rješenja. Te informacije nije jednostavno osigurati.

\section{ZAKLJUČAK}

U ovom je radu testirana efikasnost primjene metodologije fuzzy višekriterijskog linearnog programiranja u rješavanju problema planiranja proizvodnje i tehnoloških varijanti. Dobiveni rezultati ukazuju na visoku razinu efikasnosti primijenjene metodologije Opisani pristup traženja rješenja zadanog problema u nejasnom okruženju ima značajne prednosti u odnosu na upotrebu nekih drugih metoda koje su također upotrijebljene za rješavanje navedenoga problema (metoda STEM i SWT). Metoda fuzzy višekriterijskog linearnog programiranja od donositelja odluke traži informaciju o njegovim aspiracijama izraženim kroz određivanje donje i gornje granice vrijednosti funkcija cilja i ograničenja, što za donositelja odluke može jednostavno osigurati oslanjajući se na vrijednosti funkcija cilja iz tablice marginalnih rješenja. Ova je metoda također jednostavna za korištenje.

\section{LITERATURA}

1. Abd El_Wahed, W. F., Lee, S. M. (2006). Interactive fuzzy goal programming for multi-objective transportation problems, Omega 34: 158-166.

2. Baky, I. A. (2010). Solving multi-level multi-objective linear programming problems through fuzzy goal programming approach, Applied Mathematical Modelling 34(9): 2377-2387.

3. Barković, D. (1997) Operacijska istraživanja, Sveučilište Josipa Jurja Strossmayera u Osijeku, Ekonomski fakultet Osijek, Osijek. 
4. Bronstein, I. N., Semendjajew, K. A., Musiol, G., Muhlig, H. (2004). Matematički priručnik, Zagreb: Golden marketing - Tehnička knjiga.

5. Hannan, E. L. (1981). Fuzzy programming with multiple fuzzy goals, Fuzzy sets and systems 6: 235-248.

6. Hu, C.-F., Teng, C.-J., Li, S.-Y. (2007). A fuzzy goal programming approach to multiobjective optimization problem with priorities, European Journal of Operational Research 176: 1319-1333.

7. Ignizio, J. P. (1982). On the rediscovery of fuzzy goal programming, Decision Science 13: 331-336.

8. Kumar, A., Kaur, J. (2013). General Form of Linear Programming Problems with Fuzzy Parameters. Journal of Applied Research and Technology 11: 629-635.

9. Kumar, A., Kaur, J., Singh, P. (2011). A new method for solving fully fuzzy linear programming problems. Elsevier 35: 817-823.

10. Lai, Y.-J., Hwang, C.-L. (1996). Fuzzy Multiple Objective Decision Making: Methods and Applications, Springer, Berlin Heidelberg.

11. Matejaš, J, Perić, T. (2014). A new iterative method for solving multiobjective linear programming problem. Applied Mathematics and Computation 243:746-754.

12. Mohamed, R. H. (1996). The relationship between goal programming and fuzzy programming, Fuzzy Sets and Systems 89: 215-222.

13. Narasimhan, R. (1980). Goal programming in a fuzzy environment, Decision Science 11: 325-336.

14. Narasimhan, R. (1981). On fuzzy goal programming - some comments, Decision Science 12: 532-538.

15. Ohta, H., Yamaguchi, T. (1996). Linear fractional goal programming in consideration of fuzzy solution, European Journal of Operational Research 92: 157-165.

16. Pal, B. B., Moitra, B. N., Maulik, U. (2003). A goal Programming procedure for fuzzy multiobjective linear fractional programming problems, Fuzzy Sets and Systems 139: 395-405.

17. Parra, M. A., Terol, A. B., Uria, M.V.R. (2001). A fuzzy goal programming approach to portfolio selection, European Journal of Operational Research 133: 287-297.

18. Perić, T. (2008). Višekriterijsko programiranje - metode i primjene, Zagreb: Alka script d.o.o.

19. Perić, T., Bratić, F. (2015). Production Plan and Technological Variants Optimization by Goal Programming Methods, International Journal of Economics and Management Engineering 9(6): 1952-1958.

20. Sharma, D. K., Jana, R. K., Gaur, A. (2007). Fuzzy goal programming for agricultural land allocation problems. Yugoslav Journal of Operations Research 17(1): 31-42.

21. Yang, T., Ignizio, J. P., Kim, H. J. (1991) Fuzzy programming with nonlinear membership functions: piecewise linear approximation, Fuzzy sets and systems 41: 39-53.

22. Zadeh L. A. (1965). Fuzzy sets, Information and Control 8: 338-353.

23. Zimmermann H. J. (1978). Fuzzy programming and linear programming with several objective functions. Fuzzy Sets and Systems 1: 45-55. 